\title{
Dense shelf water cascading in the northwestern Mediterranean during the cold winter 2005: Quantification of the export through the Gulf of Lion and the Catalan margin
}

\author{
C. Ulses, ${ }^{1,2}$ C. Estournel, ${ }^{1}$ P. Puig, ${ }^{3}$ X. Durrieu de Madron, ${ }^{4}$ and P. Marsaleix ${ }^{1}$ \\ Received 11 January 2008; revised 20 February 2008; accepted 5 March 2008; published 11 April 2008.
}

[1] Dense shelf water cascading in the northwestern Mediterranean Sea during winter 2005, which was shown to cause large erosion in the canyons and to influence deep benthic ecosystem, was investigated using numerical modeling validated with temperature and current observations. Intense dense water formation took place on the Gulf of Lion and Catalan shelves. Dense shelf water was transferred to the deep basin through three pathways. The Cap de Creus canyon in the western Gulf of Lion already identified as a huge pathway was shown to export about $1000 \mathrm{~km}^{3}$ of dense water during two months. The Palamós and Blanes canyons located on the Catalan margin were shown to be important pathways for water formed locally and for water transiting from the Gulf of Lion. After the cascading period, dense shelf water was transported mostly toward the Balearic Sea. Citation: Ulses, C., C. Estournel, P. Puig, X. Durrieu de Madron, and P. Marsaleix (2008), Dense shelf water cascading in the northwestern Mediterranean during the cold winter 2005: Quantification of the export through the Gulf of Lion and the Catalan margin, Geophys. Res. Lett., 35, L07610, doi:10.1029/2008GL033257.

\section{Introduction}

[2] Dense shelf water cascading (DSWC) has been mainly observed in high latitudes locations, although this process is also found in mid-latitude regions submitted to cold and dry continental winds that impose sustained and strong wintry heat and water losses to the sea surface [Ivanov et al., 2004]. $3 \mathrm{D}$ numerical modeling has allowed progress in understanding of the down-slope transport of dense shelf water by examining the role of bathymetric features, eddies and baroclinic instabilities [Chapman and Gawarkiewicz, 1995; Tanaka and Akitomo, 2001]. DSWC, which is recognized as a major process of shelf - deep ocean exchanges, has multiple impacts. It contributes to the ventilation of the intermediate and deep waters, modifies the seabed along its path by eroding and depositing sediments, efficiently transports pollutants and organic matter accumulated in the shelf sediments towards the slope and the basin, and finally is

\footnotetext{
${ }^{1}$ Laboratoire d'Aérologie-CNRS-Université de Toulouse, Toulouse, France.

${ }^{2}$ Also at Centre for Estuarine and Marine Ecology, Netherlands Institute of Ecology, Yerseke, Netherlands.

${ }^{3}$ Institut de Ciences del Mar, CSIC, Barcelona, Spain.

${ }^{4}$ Centre de Formation et de Recherche sur l'Environnement MarinCNRS-Université de Perpignan, Perpignan, France.
}

Copyright 2008 by the American Geophysical Union. 0094-8276/08/2008GL033257 suspected to sustain the deep ecosystems and enhance biological diversity. The characterization of the major DSWC pathways and the accurate quantification of the off-shelf export of water are required to refine budgets of associated elements.

[3] Recently, several events of DSWC have been documented in the Gulf of Lion (GoL), located in the northwestern Mediterranean Sea (Figure 1). A substantial documentation was obtained during and after the severe winter 2005 bringing together a characterization of the cascading into a canyon and an evidence of dispersion in the deep basin. Canals et al. [2006] estimated from current meter and hydrological observations that about $750 \mathrm{~km}^{3}$ of shelf water (2/3 of the shelf volume) cascaded in 40 days through the Cap de Creus canyon (CCC) at the western end of the GoL. They also established the presence in April of a near-bottom layer of dense shelf water at $2100 \mathrm{~m}$ depth in the centre of the GoL. On the Catalan slope, about $100 \mathrm{~km}$ south of the Cap de Creus promontory, Font et al. [2007] observed at $1890 \mathrm{~m}$ deep, in early March, the passing by of cold and low-salinity water, which was attributed to the cascading either from the GoL or from a source on the Catalan shelf. During summer 2005, López-Jurado et al. [2005] observed negative anomalies of temperature and salinity below $2000 \mathrm{~m}$ in the deep Balearic Sea associated with positive anomalies between $1400 \mathrm{~m}$ and $2000 \mathrm{~m}$. This new deep water was suspected to result from several processes, one of them being the DSWC from the GoL and the others linked to deep convection and changes of the water mass characteristics originating from the eastern Mediterranean Sea.

[4] In the present paper, we used hydrodynamic modeling, after comparison with published observations, to investigate the formation and dispersion of dense water during this exceptional event. The first outcome is a quantification of the export from the GoL shelf during winter 2005. A second and new result concerns the Catalan margin. We show that it is a place of dense water formation and also a major transit pathway for a part of the dense water formed in the GoL.

\section{Material and Methods}

[5] We used the primitive equation ocean circulation model SYMPHONIE [Marsaleix et al., 2008; Ulses et al., 2008] to study DSWC in the northwest Mediterranean during winter 2005. This model is based on the Boussinesq and hydrostatic assumptions. Horizontal diffusion is implicitly computed through the tracer advection scheme given by a linear combination of a centered and an upstream scheme. The ratio of this combination is deduced from a second order analysis of the local density field. As far as momen- 


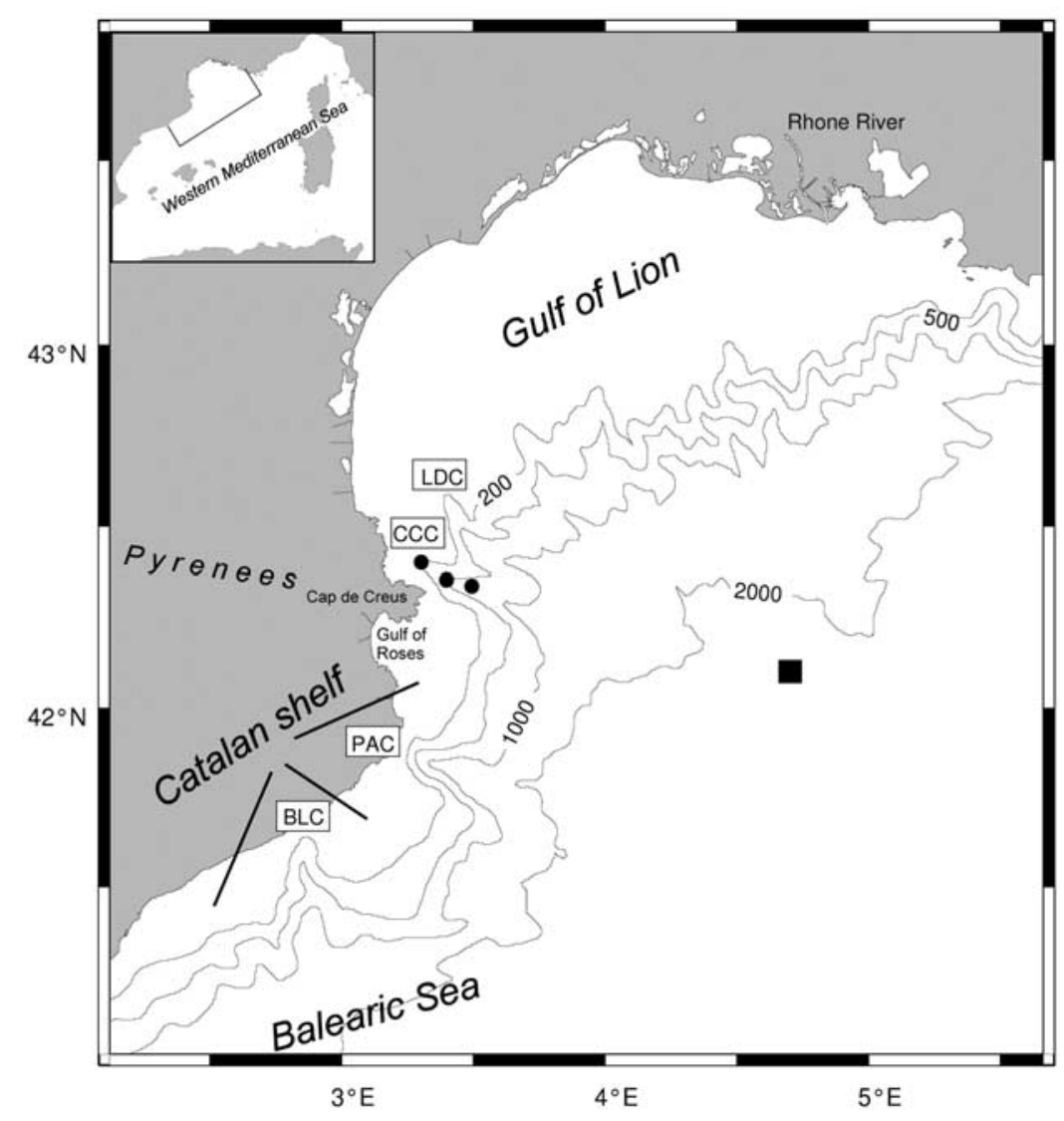

Figure 1. Bathymetric map of the Gulf of Lion and the Catalan margin with the position of the moorings in the Cap de Creus canyon (CCC, black points) and of the meteorological buoy (black square). BLC, Blanes canyon; PAC, Palamós canyon; and LDC, Lacaze-Duthiers canyon. The insert delineates the modeling domain in the northwestern Mediterranean Sea.

tum equations are concerned, horizontal viscosity $v_{h}$ is related to $|u|$, the current magnitude, and to $\Delta x$, the size of the grid box in the considered direction, namely, $v_{h}=$ $|u| \Delta x / 2$. We used a succession of nested models. First, simulations were carried out with a regional scale model (40 sigma-step vertical levels and $3 \mathrm{~km}$ horizontal resolution) extending from the Ligurian Sea to the Ibiza channel, using the configuration implemented in the framework of the Mediterranean Forecasting System project (see Estournel et al. [2007] for details). Daily averaged outputs of the latter model provided initial and open boundary conditions for the so-called coastal model (40 sigma-step vertical levels and $1.5 \mathrm{~km}$ horizontal resolution) that covers the GoL and the Catalan margin as indicated in the insert in Figure 1. The initial and boundary conditions of the regional model for salinity were corrected from a negative bias in the basin scale model fields detected from comparison with in situ profiles. Momentum, heat and salt fluxes at the air-sea interface were computed with bulk formulae, using air parameters provided by the weather forecasting model ALADIN (also providing radiative fluxes) and the sea surface temperature computed by the hydrodynamic model. Freshwater discharges were prescribed at 14 major river mouths of the study area. The simulation began on early November 2004.
[6] Temperature and current were measured during winter 2005 along the CCC axis at 200, 500 and $750 \mathrm{~m}$ depth (Figure 1) in the framework of the EU-NA EuroSTRATAFORM project (see Canals et al. [2006] for details). Wind during the study period was measured at the "Lion" meteorological buoy (Météo-France) located at 42.1 N, 4.7 E (Figure 1).

\section{Results and Discussion}

[7] Figure 2a presents the time-series of the wind measured on the meteorological buoy offshore of the GoL and from the ALADIN model at the corresponding grid point. The correlation of 0.95 between the two series and the small bias $\left(0.43 \mathrm{~m} \mathrm{~s}^{-1}\right)$ indicate the quality of the wind forcing (chronology of events and representation of maxima). Figure $2 \mathrm{~b}$ presents the time series of the total heat and radiative flux for the entire GoL and Catalan shelves. The winter and more precisely the period from 15 December 2004 to 10 March 2005 were characterized by a large number of strong northern wind days associated with large heat losses. López-Jurado et al. [2005] found from the NCEP/NCAR reanalysis that the cumulated heat loss from December to March of this year for the GoL region was the largest of all winters since 1948. The heat loss over the GoL was higher than over the Catalan shelf (mean difference: 
a

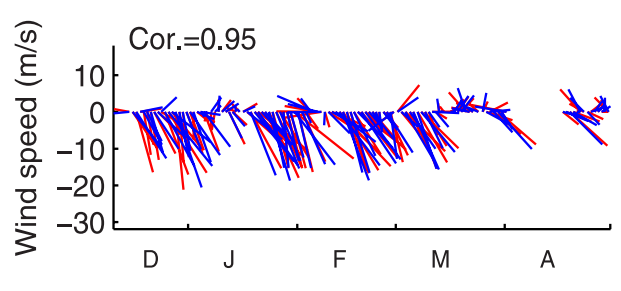

C

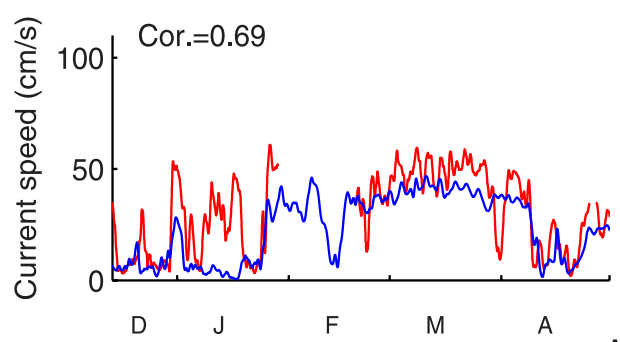

b
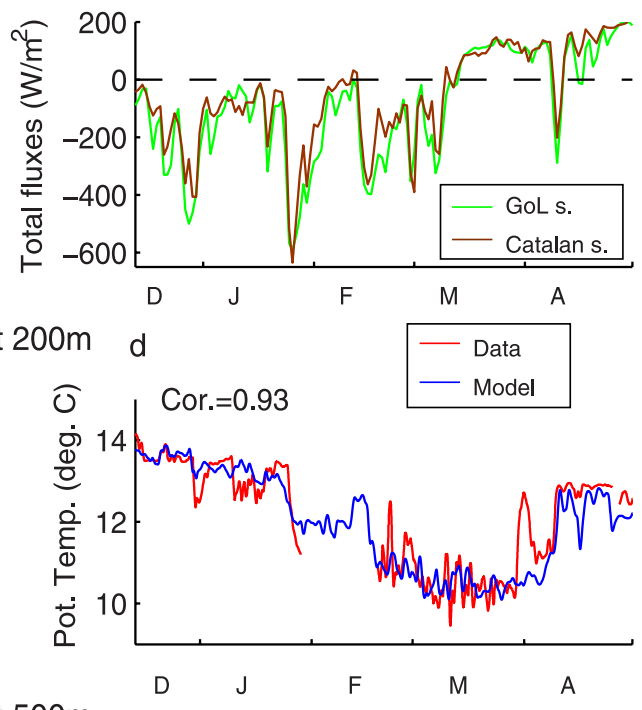

At $500 m$
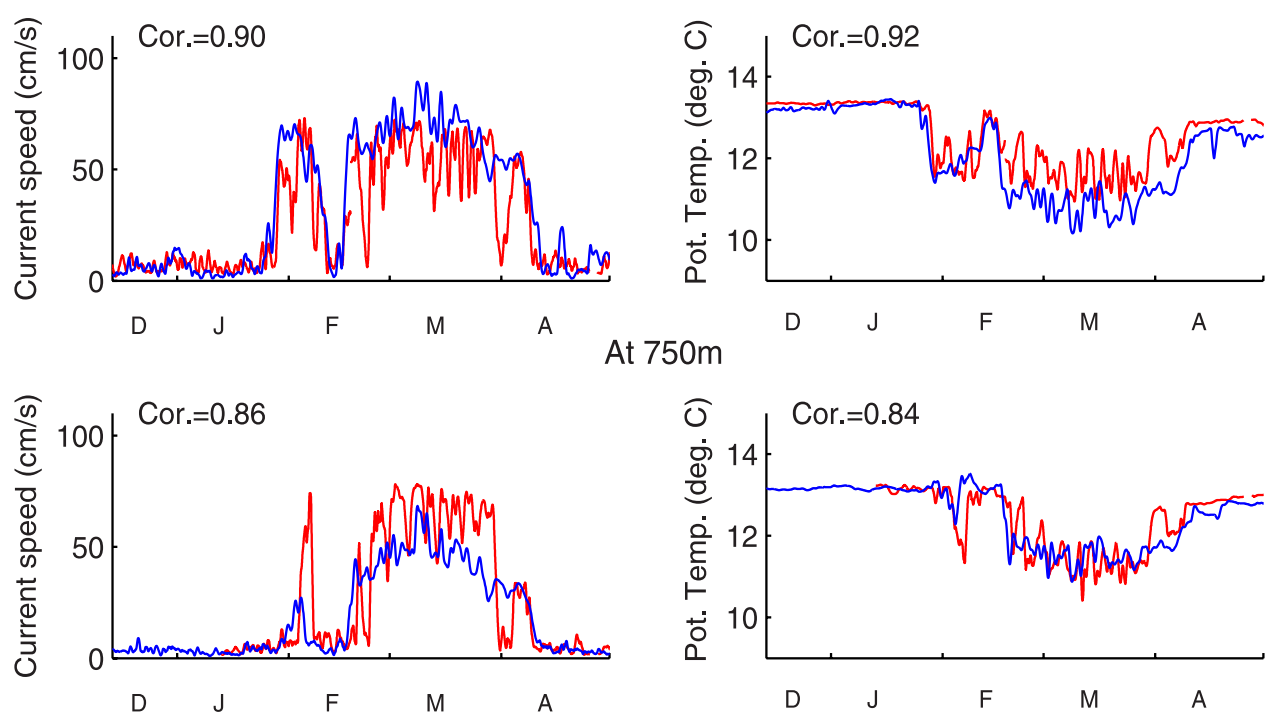

Figure 2. Time series of (a) wind $\left(\mathrm{m} \mathrm{s}^{-1}\right.$ ) observed at the meteorological buoy "Lion" located at $42.1 \mathrm{~N}, 4.7 \mathrm{E}$ (in red) and simulated by the ALADIN model (in blue), (b) total heat and radiative fluxes ( $\mathrm{W} \mathrm{m}^{-2}$ ) on the Gulf of Lion (green) and Catalan (brown) shelves, and (c) near-bottom current speed $\left(\mathrm{cm} \mathrm{s}^{-1}\right)$ and (d) potential temperature $\left({ }^{\circ} \mathrm{C}\right)$, observed (in red) and simulated (in blue) at 200, 500, and $750 \mathrm{~m}$ in the Cap de Creus canyon from mid-December 2004 to the end of April 2005 .

$40 \mathrm{~W} \mathrm{~m}^{-2}$ ). It presented in this latter region a strong south to north gradient with a maximum near the Cap de Creus. Looking at another factor that can (negatively) influence the dense water formation, the Rhône River discharge (that represented $90 \%$ of the total river discharge of the modeled region) was characterized, after a flood at the beginning of November, by low discharges along the winter period. The average discharge between December and March was about $1400 \mathrm{~m}^{3} \mathrm{~s}^{-1}$, which is lower than the December-March mean discharge $\left(\sim 2000 \mathrm{~m}^{3} \mathrm{~s}^{-1}\right)$ and the lowest value since 1993. All these factors made winter 2005 an exceptional year for the DSWC.

[8] Figures 2c and 2d present the comparison between the time series of, respectively, current speed and temperature, measured and simulated at 200, 500 and $750 \mathrm{~m}$ depth in the CCC. The large correlation coefficients between observations and model outputs (most often larger than 0.80 and reaching 0.93 ) quantify the agreement shown on the figures. The intensity of currents is well represented by the simulation (except the second half of March at $750 \mathrm{~m}$ depth) as well as a number of events that can be observed on the temperature and current time series. Schematically, at 500 and $750 \mathrm{~m}$ depth, three phases of DSWC marked by simultaneous current increases and temperature decreases can be distinguished. The first one began at the end of January during a period of strong meteorological forcing and lasted about 15 days. DSWC stopped during a period of moderate wind and then restarted around the end of February during a three-week period of strong wind, until the end of March. A last short event was observed during the beginning of April. 
[9] Figures 3a and $3 \mathrm{~b}$ present the main characteristics of DSWC on 13 March 2005. Figure 3a represents the density and current velocity at $10 \mathrm{mab}$, and Figure $3 \mathrm{~b}$ represents a vertical density section crossing the Gulf of Roses shelf and

a
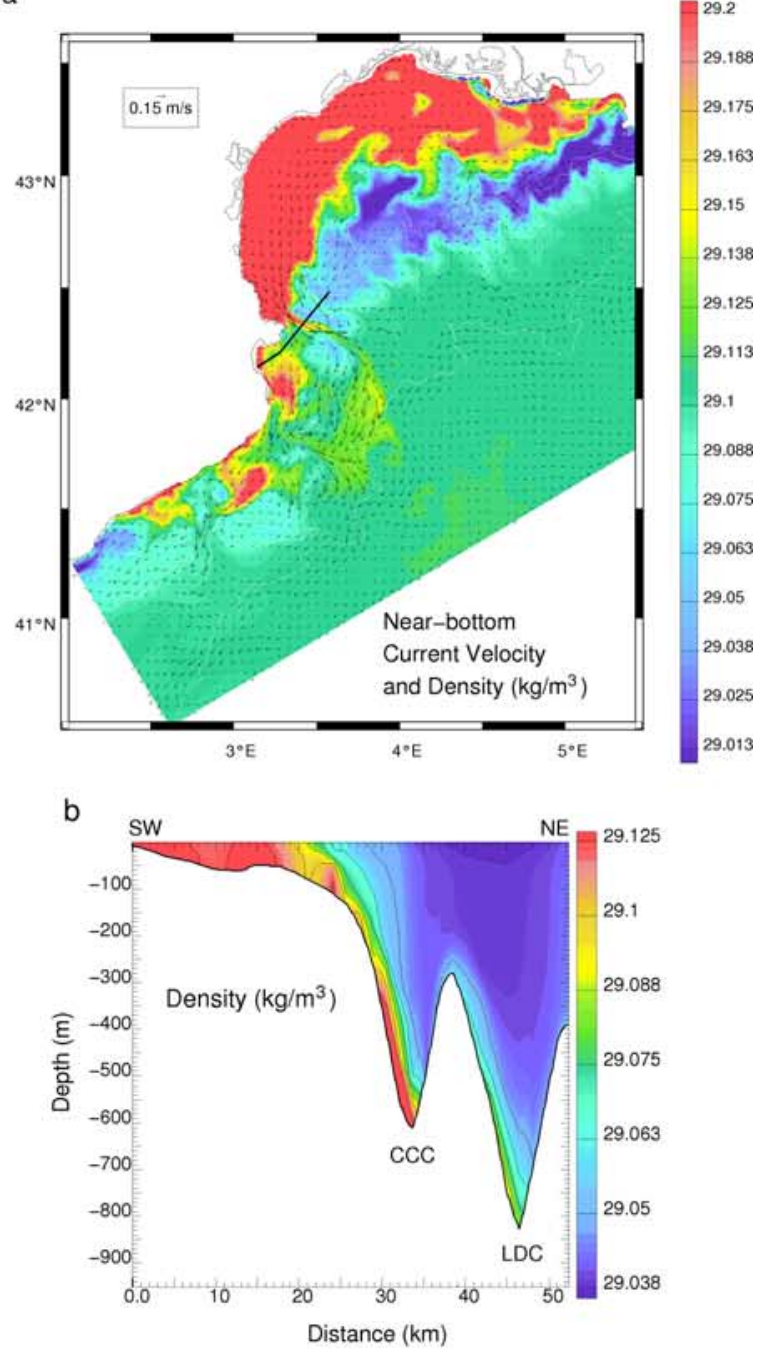

c

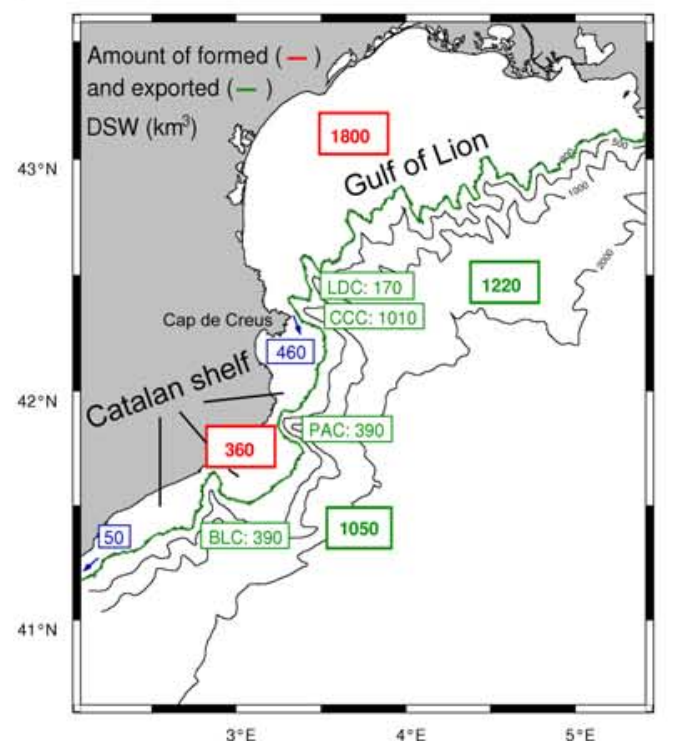

the Cap de Creus and Lacaze-Duthiers canyons (see position on Figure 3a). The places of formation concerned mainly the GoL but also some areas on the Catalan shelf as the Gulf of Roses where the shelf is slightly widening and local river discharge remained low (from December to March the mean river discharge was less than $5 \mathrm{~m}^{3} \mathrm{~s}^{-1}$ ). Figures $3 a$ and $3 b$ show that DSW exited the GoL within a shallow plume and a deep one. The shallow plume flowed around the Cap de Creus promontory and entered on the Catalan shelf where it propagated along the $100-150 \mathrm{~m}$ isobaths. This dense water was formed in shallow regions along the coast located at the extreme southwest of the GoL $(\sim$ south of $42.6 \mathrm{~N})$ in a place where the wind is generally very strong due to the barrier effect of the west-east Pyrenees Mountain chain ending at the Cap de Creus. Concerning the deep plume, the CCC was clearly the main pathway for DSWC due to its strategic position at the point where the cyclonic circulation of the GoL dense water converged, as already showed through modeling by Dufau-Julliand et al. [2004]. This canyon collected the major part of dense water formed north of $42.6 \mathrm{~N}$ and west of $4 \mathrm{E}$. Because of the relatively steep bottom slope on the inner shelf, the dense water flowed with a strong cross-slope component from the formation areas along the coast toward the centre of the shelf (around the 90-100 m deep), where it weakened due to the more gentle bottom slope. The dense water flowed southwardly until impinging the head of the westernmost canyons (especially the CCC). On the Catalan margin, the Palamós and Blanes canyons which deeply incise the shelf appeared as efficient pathways for DSWC down to the deep basin. The Palamós canyon collected dense water from the GoL, skirting the Cap de Creus promontory, as well as water formed in the Gulf of Roses. It was a mixture of these waters that was probably observed, about $20 \mathrm{~km}$ south of the Palamós canyon axis, during March by Font et al. [2007]. At this site, the model produces a negative temperature anomaly of $0.35^{\circ} \mathrm{C}$ during a 40-day period starting from 9 March that is consistent with these observations. Further south, the Blanes canyon collected the dense water formed between the Blanes and Palamós canyons, and that transiting between the coast and the Palamós canyon head. In the canyons, dense water cascaded as a 50-m thick plume pressed along the southern wall (Figure 3b), which is in very good agreement with observations taken in February in the CCC [Canals et al., 2006]. As noted by Chapman and Gawarkiewicz [1995], the bathymetric constraints in the canyons are strong and triggered the propagation of dense water as a plume in opposition with the wide shelf in the northern GoL where

Figure 3. (a) Density anomaly $\left(\mathrm{kg} \mathrm{m}^{-3}\right)$ and current velocity simulated 10 meters above the bottom for 13 March 2005. 200, 500, 1000, and $2000 \mathrm{~m}$ isobaths are superimposed. (b) Vertical section of density $\left(\mathrm{kg} \mathrm{m}^{-3}\right)$ on 13 March 2005 (location is indicated on Figure 3a). (c) Estimated amount $\left(\mathrm{km}^{3}\right)$ of dense water formed by surface fluxes (in red) and exported to the slope at $200 \mathrm{~m}$ depth (in green) and through the extremities of the Gulf of Lion and Catalan shelves (in blue) for winter 2005. The limit across which the shelf to slope fluxes were calculated is indicated in green thick line. 
baroclinic instabilities developed at the edge of the formation zone. In our simulation, DSW reaching the deep basin (depth $>1500 \mathrm{~m}$ ) passed only through the Cap de Creus, Palamós and Blanes canyons. This dense water spread during the following months with velocity of $5-10 \mathrm{~cm} \mathrm{~s}^{-1}$ mostly toward the Balearic Sea even if a large filament stretching northeastward was present at the end of April offshore of the GoL, around $42.3 \mathrm{~N}, 4.5 \mathrm{E}$, presenting a negative bottom temperature anomaly of $\sim 0.05^{\circ} \mathrm{C}$ in accordance with the observations of Canals et al. [2006]. In July, a large part of dense water was advected southwestward out of our modeling domain but a pool of water characterized by a similar negative temperature anomaly was still present south of the Blanes canyon, in accordance with the observations of López-Jurado et al. [2005, Figures 3c and 3e].

[10] DSW fluxes were computed from the model outputs at the extremities of the GoL and Catalan shelves, and through the shelf edge at $200 \mathrm{~m}$. DSW were distinguished from surrounding waters using a density criterion defined as the average density of slope water between 200 and $400 \mathrm{~m}$ depth. The formation of DSW at the surface by atmospheric fluxes was computed using the method of Walin [1982]. Figure $3 \mathrm{c}$ presents the amount formed in and exported from the GoL and Catalan margins.

[11] On the GoL shelf, $1800 \mathrm{~km}^{3}$ of DSW were formed by surface buoyancy fluxes. The formation was evenly distributed on the eastern and western areas. $1220 \mathrm{~km}^{3}$ (68\% of formed DSW) were advected down the slope, mostly through the westernmost canyons: 170 and $1010 \mathrm{~km}^{3}$ transited through the Lacaze-Duthiers canyon and CCC respectively. Our estimate of DSW export through the CCC restricted to the 40-day event from mid-February to end of March is close to the value of $750 \mathrm{~km}^{3}$ evaluated by Canals et al. [2006] at the same period. $460 \mathrm{~km}^{3}$ of DSW formed on the GoL were advected towards the Catalan shelf. On this shelf, $360 \mathrm{~km}^{3}$ of DSW were formed at the surface. The formation was mostly located at the north of the Blanes canyon. $1050 \mathrm{~km}^{3}$ were exported towards the Catalan slope. The difference between the amount of water formed at the surface and that exported on the slope is explained by mixing processes that increased density of water masses surrounding formed water. With a respective volume of $390 \mathrm{~km}^{3}$, the Palamós and Blanes canyons contributed to $74 \%$ of DSW export to the Catalan slope and confirm the major role of canyons in down-slope export of DSW. By varying the density criteria by $\pm 0.01 \mathrm{~kg} \mathrm{~m}^{-3}$ or using instead of density criteria, temperature criteria between $12.6 \pm 0.1{ }^{\circ} \mathrm{C}$ defined according to temperature anomalies at $200 \mathrm{~m}$ depth (Figure 2d), the uncertainties on these export flux estimates were evaluated to be generally less than $25 \%$.

[12] Béthoux et al. [2002] inferred that $440 \mathrm{~km}^{3}$ of DSW were exported on the GoL slope during the intense 1999 cascading event. Ulses et al. [2008] estimated at $75 \mathrm{~km}^{3}$ the DSWC for the GoL during the mild winter 2004. This suggests that overflow of DSW on the GoL slope presents an interannual variability within one order of magnitude. The winter 2005 is rather believed to represent the upper range of the off-shelf export. The mean flux per unit length was estimated at $\sim 0.8 \mathrm{~m}^{2} / \mathrm{s}$, considering a cascading duration of 80 days and a shelf edge length of $400 \mathrm{~km}$. This value is in the upper range of the flux estimates for other cascading events worldwide (e.g. $0.5 \mathrm{~m}^{2} / \mathrm{s}$ for the Barents Sea and Rockall Bank cascades) [Shapiro et al., 2003]. However, due to the relatively short duration and shelf length, the annual flux - evaluated at $0.07 \mathrm{~Sv}$ - is in the lower range of DSWC flux worldwide [Shapiro et al., 2003]. The 2005 event corresponds to $\sim 3.5$ to $7 \%$ of the flow in the straits of Gibraltar and Sicily (1-2 Sv) [Millot, 1999]. The DSWC generally contributes to the formation of Western Mediterranean Intermediate Water [Dufau-Julliand et al., 2004]. During the winter 2005, as in the case of the 1999 cascade event [Béthoux et al., 2002], DSW reached the bottom of the basin and thus also contributed to the formation of the Western Mediterranean Deep Water. It is believed that offshore deep convection in the GoL [Medoc Group, 1970] produces much larger volumes of deep dense water than DSWC. However, due to its coastal origin, we can expect that DSWC exports larger quantities of sediment, organic matter and contaminants. Assuming particulate and dissolved organic carbon concentration ranges of $0.01-$ $0.08 \mathrm{~g} \mathrm{~m}^{-3}$ and $0.6-1.2 \mathrm{~g} \mathrm{~m}^{-3}$ respectively [Cauwet et al., 1997], we estimated the off-shelf export of total organic carbon induced by DSWC to range between 1.4 and $2.9 \times$ $10^{6}$ tons. Relating this export to the GoL - Catalan shelf area $\left(\sim 1.4 \times 10^{10} \mathrm{~m}^{2}\right)$, we found an export flux of $99-$ $207 \mathrm{gC} \mathrm{m}^{2} \mathrm{y}^{-1}$ comparable to the annual primary production in the GoL estimated by Conan et al. [1998] at 140$150 \mathrm{gC} \mathrm{m}^{2} \mathrm{y}^{-1}$.

\section{Conclusions}

[13] An ocean circulation modeling, validated against in situ hydrological and current data, was used to study and quantify the DSW formation and cascading on the northwestern Mediterranean slope during the abnormally cold winter 2005. Our study allows a DSW fate description, and an estimate of the volume of dense water formed on the GoL and Catalan shelves, and of the fraction that cascaded down-slope.

[14] The dense water formed on the GoL shelf by persistent and very cold continental winds was transferred mostly through the CCC and towards the Catalan shelf. The dense water exported through the canyon was advected towards the south along the Catalan slope. It is shown that the Catalan shelf, also experiencing strong heat losses, produced a significative dense water amount. The Palamós and Blanes canyons largely contributed to the down-slope flow of DSW. The Catalan margin appeared as a major place for dense shelf water export towards the deep basin. The four southernmost canyons (from Lacaze-Duthiers to Blanes) contributed to about $86 \%$ of the total export. Most of exported dense shelf water eventually spread in the Balearic Sea during the months following the cascading period.

[15] The present study shows that the 2005 cascading event was responsible for large export of shelf water that contributed to the renewal of the Western Mediterranean Deep Water. Concomitant observations showed that it also induced significant erosion and sedimentary furrow formation in canyons [Canals et al., 2006] and influenced deepsea shrimp populations [Company et al., 2008]. 
[16] Acknowledgments. We thank Météo-France for the ALADIN model outputs and wind data at the "Lion" buoy. We are grateful to the Compagnie Nationale du Rhône, the Banque HYDRO and the Agència Catalana de l'Aigua for providing river discharge. The moorings in the Cap de Creus canyon were funded by the US Office of Naval Research (ONR Grant N00014-04-1-0379). This study was supported by the EU Eurostrataform project and by CNRS INSU through the LEFE-IDAO program.

\section{References}

Béthoux, J. P., X. Durrieu de Madron, F. Nyffeler, and D. Tailliez (2002), Deep water in the western Mediterranean: Peculiar 1999 and 2000 characteristics, shelf formation hypothesis, variability since 1970 and geochemical inferences, J. Mar. Syst., 33-34, 117-131.

Canals, M., P. Puig, X. Durrieu de Madron, S. Heussner, A. Palanques, and J. Fabres (2006), Flushing submarine canyons, Nature, 444, 354-357.

Cauwet, G., A. Miller, S. Brasse, G. Fengler, R. F. C. Mantoura, and A. Spitzy (1997), Dissolved and particulate organic carbon in the western Mediterranean Sea, Deep Sea Res., Part II, 44, 769-779.

Chapman, C., and G. Gawarkiewicz (1995), Offshore transport of dense water in the presence of a submarine canyon, J. Geophys. Res., 100, $13,373-13,387$.

Company, J. B., et al. (2008), Climate influence on deep sea populations, PLOS ONE, 3(1), e1431, doi:10.1371/journal.pone.0001431.

Conan, P., M. Pujo-Pay, P. Raimbault, and M. Leveau (1998), Variabilité hydrologique et biologique au sein du Courant Nord Mediterranéen à l'entrée du Golfe du Lion, II. Bilan de la productivité sur le bord interne du courant, Oceanol. Acta, 21, 767-781.

Dufau-Julliand, C., P. Marsaleix, A. Petrenko, and I. Dekeyser (2004), Three-dimensional modelling of the Gulf of Lion's hydrodynamics (northwestern Mediterranean) during January 1999 (MOOGLI 3 experiment) and late winter 1999: Western Mediterranean Intermediate Water's (WIW) formation and its cascading over the shelf break, J. Geophys. Res., 109, C11002, doi:10.1029/2003JC002019.

Estournel, C., F. Auclair, M. Lux, C. Nguyen, and P. Marsaleix (2007), "Scale oriented" embedded modeling of the north-western Mediterranean in the frame of MFSTEP, Ocean Sci. Discuss., 4, 145-187.

Font, J., P. Puig, J. Salat, A. Palanques, and M. Emelianov (2007), Sequence of hydrographic changes in the NW Mediterranean deep water due to exceptional winter 2005, Sci. Mar., 72, 339-346.
Ivanov, V. V., G. I. Shapiro, J. M. Huthnance, D. L. Aleynik, and P. N. Golovin (2004), Cascades of dense water around the world ocean, Prog. Oceanogr., 60, 47-98.

López-Jurado, J.-L., C. Gonzáles-Pola, and P. Vélez-Belchí (2005), Observation of an abrupt disruption of the long-term warming trend at the Balearic Sea, western Mediterranean, in summer 2005, Geophys. Res. Lett., 32, L24606, doi:10.1029/2005GL024430.

Marsaleix, P., F. Auclair, J. W. Floor, M. J. Herrmann, C. Estournel, I. Pairaud, and C. Ulses (2008), Energy conservation issues in sigmacoordinate free-surface ocean models, Ocean Modell., 20, 61-89.

Medoc Group (1970), Observation of formation of deep water in the Mediterranean Sea, Nature, 227, 1037-1040.

Millot, C. (1999), Circulation in the western Mediterranean Sea, J. Mar. Syst., 20, 423-442.

Shapiro, G. I., J. M. Huthnance, and V. V. Ivanov (2003), Dense water cascading off the continental shelf, J. Geophys. Res., 108(C12), 3390, doi:10.1029/2002JC001610.

Tanaka, K., and K. Akitomo (2001), Baroclinic instability of density current along a sloping bottom and the associated transport process, J. Geophys. Res., 106, 2621-2638.

Ulses, C., C. Estournel, J. Bonnin, X. Durrieu de Madron, and P. Marsaleix (2008), Impact of storms and dense water cascading on shelf-slope exchanges in the Gulf of Lion (NW Mediterranean), J. Geophys. Res., 113, C02010, doi:10.1029/2006JC003795.

Walin, G. (1982), On the relation between sea-surface heat flow and the thermal circulation in the ocean, Tellus, 34, 187-195.

X. Durrieu de Madron, Centre de Formation et de Recherche sur l'Environnement Marin-CNRS-Université de Perpignan, F-66860 Perpignan, France.

C. Estournel and P. Marsaleix, Laboratoire d'Aérologie-CNRSUniversité de Toulouse, 14 avenue E. Belin, F-31400 Toulouse, France.

P. Puig, Institut de Ciences del Mar, CSIC, Passeig Maritim de la Barceloneta, 37-49, E-08003 Barcelona, Spain.

C. Ulses, Centre for Estuarine and Marine Ecology, Netherlands Institute of Ecology, P.O. Box 140, NL-4400 AC Yerseke, Netherlands. (c.ulses@ nioo.knaw.nl) 